\title{
OBSERVATIONS OF THE EFFECTS OF 17 $\boldsymbol{\alpha}-$ METHYLTESTOSTERONE (MT) ON THE GONADS, TESTES OF Clarias gariepinus BROODSTOCKS AFTER HORMONE-TREATED FEEDING TRIAL.
}

\author{
Robert, E.A. \\ ${ }^{1}$ National Institute for Freshwater Fisheries Research, New Bussa, Niger State, Nigeria. \\ Corresponding author: Robert, E.A. \\ Email: ememrobert@gmail.com
}

DOI: $10.31364 /$ SCIRJ/v9.i10.2021.P1021888

http://dx.doi.org/10.31364/SCIRJ/v9.i10.2021.P1021888

\begin{abstract}
Seven hundred and sixty-five Clarias gariepinus fry were stocked in nine concrete tanks. Stocking density was eighty-five fry per 2 X 2 X 1 metre square tank. Experiment duration for hormone usage was three hundred and sixty-six (366) days. Feeding with the hormone stopped at 366 days and normal feeding without the use of the hormone picked up for another 365 days before findings were carried out. Fry were fed $0.2 \mathrm{~mm}$ coppens feed mixed with $17 \alpha$-Methyltestosterone (MT) at $10 \%$ of the fish' body weight from start of the experiment till month one. Fish were fed $0.8 \mathrm{~mm}$ coppens feed in month two and month three at $10 \%$ of the fish' body weight. Fish were fed $2 \mathrm{~mm}$ coppens in month four at $10 \%$ of the fish' body weight. $6 \mathrm{~mm}$ coppens feed was administered from month five till twelve months at $5 \%$ of the fish' body weight. Feeding without the hormone continued for another 365 days at $5 \%$ of the fish' body weight. Mean initial weight ranged from $0.049 \mathrm{~g}$ to $0.06 \mathrm{~g}$. Mean final weights ranged from $6.4 \mathrm{~g}$ to $8.5 \mathrm{~g}$. Weights of the gonads ranged from $31.5 \mathrm{~g}$ to $117.8 \mathrm{~g}$ for the $\mathrm{C}_{50}$ treatment. Weights of the testes however, ranged from $0.8 \mathrm{~g}$ to $11.5 \mathrm{~g}$ also for the $\mathrm{C}_{50}$ treatment. Weights of the gonads for the $\mathrm{C}_{100}$ treatment ranged from $87.2 \mathrm{~g}$ to $244.4 \mathrm{~g}$, while weights of the testes for the $\mathrm{C}_{100}$ treatment were from $3.9 \mathrm{~g}$ to $18.6 \mathrm{~g}$. There were three treatments: $\mathrm{C}_{50}, \mathrm{C}_{100}, \mathrm{C}_{0}$. Treatments were in triplicates.
\end{abstract}

Keywords: Clarias gariepinus, fry, 17 $\alpha$-Methyltestosterone (MT), sex-reversal, gonads, testes.

\section{INTRODUCTION}

Aquaculture production is synonymous with ensuring food security for the teeming Nigerian populace and indeed, Africa at large (Ataguba et al., 2010). The use of hormones in aquaculture production is reported to be essential in the production of monosex populations, enhancing sex- reversal and increasing weight gain and growth in cultured fishes (Hoga et al., 2018). Treatments for sexreversal are conducted at the beginning of the fish' development before gonadal sexual differentiation takes place (Hoga et al., 2018; Almeida, 2013). The hormone, 17 $\alpha$-Methyltestosterone (MT) has reportedly yielded great results and ensured the production of allmale populations or, near all- male populations (Robert et al., 2019c). This study was undertaken to document research findings on the effects of $17 \alpha$-Methyltestosterone (MT) on the gonads and testes of Clarias gariepinus broodstocks reared from fry stage to broodstock stage. Previous reports often detail microscopic observations only making it difficult for the local fish farmer to understand scientific terms; while leaving out the effects of the hormone on fish organs after usage through visual observations.

\section{www.sciri.org}

(C) 2021, Scientific Research Journal

http://dx.doi.org/10.31364/SCIRJ/v9.i10.2021.P1021888

This publication is licensed under Creative Commons Attribution CC BY. 


\section{MATERIALS AND METHODS}

\section{Study area, source of experimental fish and water source}

This research was conducted using the indoor concrete tanks and outdoor concrete tanks of the National Institute for Freshwater Fisheries Research (NIFFR), New Bussa, Niger state. New Bussa is located on latitude $9^{\circ} 53^{\prime} \mathrm{N}$ and longitude $4^{\circ} 31^{\prime} \mathrm{N}$ (Robert et al., 2019a). Fry of Clarias gariepinus were obtained through induced breeding of Clarias gariepinus male and female broodstocks in NIFFR indoor hatchery. The Kigera Dam of NIFFR supplied water for this research duration.

\section{Experimental design}

The experimental design was a 1 × 3 × 3 factorial design.

\section{Experimental procedure}

Male and female Clarias gariepinus were selected by examining their external features which showed swollen, distended abdomens, reddish vents, easy release of eggs when pressed gently for the females; and reddish pointed genital papillae for the males. These characteristics indicated maturity in male and female Clarias gariepinus. Females were injected intramuscularly with $0.1 \mathrm{ml}$ to $0.2 \mathrm{ml}$ of ovaprim per $\mathrm{kg}$ according to the fish' body weight for treatments $\mathrm{C}_{50}$; and $0.25 \mathrm{ml}$ to $0.4 \mathrm{ml}$ of ovaprim per $\mathrm{kg}$ of the fish' body weight for treatment $\mathrm{C}_{100}$. Fishes were then weighed and returned to the holding vats for a twelve-hour latency period. After the latency period, the males were sacrificed and the milt obtained by dissecting the testes of the male fish using a surgical blade. $0.9 \%$ saline solution was added to the mixture of milt and eggs. The mixture of the eggs, milt and saline solution were stirred to aid fertilization. The eggs were then deposited on spawning mats in nine concrete $2 \times 2 \times 1 \mathrm{~m}^{2}$ indoor tanks. After the fry had absorbed their yolk sac four days after fertilization, artemia feed was introduced. This starter feed (Artemia) was mixed with $50 \mathrm{mg} / \mathrm{kg}$ inclusion level of $17 \alpha-$ Methyltestosterone (MT) for the first three indoor hatching concrete tanks labelled as $\mathrm{C}_{50}$. Artemia mixed with $100 \mathrm{mg} / \mathrm{kg}$ dosage of $17 \alpha$-Methyltestosterone (MT) were fed the fry in the next three hatching concrete tanks labelled as $\mathrm{C}_{100}$. The three hatching tanks for the control treatments were fed artemia with no mixture of $17 \alpha$-Methyltestosterone (MT) in their feed. For the purposes of this research, only the results from the treatments fed with $17 \alpha$-Methyltestosterone (MT) will be reported, as comparison studies will only reflect studies from the $\mathrm{C}_{50}$ and $\mathrm{C}_{100}$ tanks. On the seventh day, fry were transferred to the outdoor tanks. Fry were fed with $0.2 \mathrm{~mm}$ coppens feed mixed with 17 $\alpha$-Methyltestosterone (MT). From month two to month three, $0.8 \mathrm{~mm}$ coppens feed was administered to fishes. Feeding continued using $2 \mathrm{~mm}$ coppens feed in the fourth month. While, $6 \mathrm{~mm}$ coppens feed were fed fishes from the fifth month to the twelfth month. After feeding the fishes for 366 days with feed mixed with $17 \alpha$-Methyltestosterone (MT), feeding using 9 mm coppens continued for another 365 days without mixing with $17 \alpha$-Methyltestosterone (MT) and at 5\% of fish' body weight. Monthly manual www.scirj.org

(C) 2021, Scientific Research Journal

http://dx.doi.org/10.31364/SCIRJ/v9.i10.2021.P1021888

This publication is licensed under Creative Commons Attribution CC BY. 
exchange of water was carried out throughout the sampling period. Fish' genital papillae were checked during sampling every month with the aid of a biological microscope (XS Series 500) to ascertain sex-reversal.

\section{RESULTS AND DISCUSSION}

Table 1 Sex reversal of Clarias gariepinus into all-male using 17 $\alpha$-Methyltestosterone (MT) for the duration under study

\begin{tabular}{|l|l|}
\hline Treatment & Sex reversal \% \\
\hline $\mathrm{C}_{50}$ & $94 \%$ \\
\hline $\mathrm{C}_{100}$ & $93 \%$ \\
\hline
\end{tabular}

Table 2 Observations of the Gonads and Testes of the male and female Clarias gariepinus using a biological microscope

\begin{tabular}{|c|c|c|c|c|}
\hline Treatments & $\begin{array}{l}\text { Sex } \\
\text { (Clarias gariepinus) }\end{array}$ & Gonad weight (g) & Testes weight (g) & $\begin{array}{l}\text { Biological } \\
\text { observation via a } \\
\text { microsope (XS Series } \\
500)\end{array}$ \\
\hline $\mathrm{C}_{50}$ & $\hat{o},+$ + & 31.5 & 11.5 & $\begin{array}{l}\text {-Motile eggs observed } \\
\text { to be very active (eggs } \\
\text { moving) under the } \\
\text { microscope, brownish } \\
\text { eggs, circular, reddish } \\
\text { gonad (abnormal } \\
\text { looking). } \\
\text {-Watery milt }\end{array}$ \\
\hline $\mathrm{C}_{50}$ & $\hat{0},+$ o & 86.7 & 5.5 & $\begin{array}{l}\text { motile eggs, greenish } \\
\text { brown eggs. } \\
\text {-Non-motile milt. }\end{array}$ \\
\hline
\end{tabular}




\begin{tabular}{|c|c|c|c|c|}
\hline $\mathrm{C}_{50}$ & $\partial^{\lambda}$, ㅇ & 58.8 & 0.8 & $\begin{array}{l}\text {-Reddish gonad, } \\
\text { motile eggs, brownish } \\
\text { eggs. } \\
\text {-Motile milt but slow- } \\
\text { moving. }\end{array}$ \\
\hline $\mathrm{C}_{50}$ & $\partial^{\lambda}$, ㅇ & 117.8 & 4.0 & $\begin{array}{l}\text {-Reddish gonad, } \\
\text { motile eggs, slow } \\
\text { moving. } \\
\text {-Non motile milt. }\end{array}$ \\
\hline $\mathrm{C}_{50}$ & $\partial^{\lambda}, q$ & 70.0 & 4.0 & $\begin{array}{l}\text { motile eggs. } \\
\text {-Non motile milt. }\end{array}$ \\
\hline $\mathrm{C}_{100}$ & के, $\hat{0}$ & 165.4 & 18.6 & $\begin{array}{l}\text {-Reddish gonad, no } \\
\text { motile eggs, greenish } \\
\text { eggs, oval gonads. } \\
\text {-Watery milt. }\end{array}$ \\
\hline $\mathrm{C}_{100}$ & q,$\hat{0}$ & 166.5 & 8.9 & $\begin{array}{l}\text { motile eggs, slow } \\
\text { moving eggs, } \\
\text { brownish eggs. } \\
\text {-Motile milt, ripe milt. }\end{array}$ \\
\hline
\end{tabular}




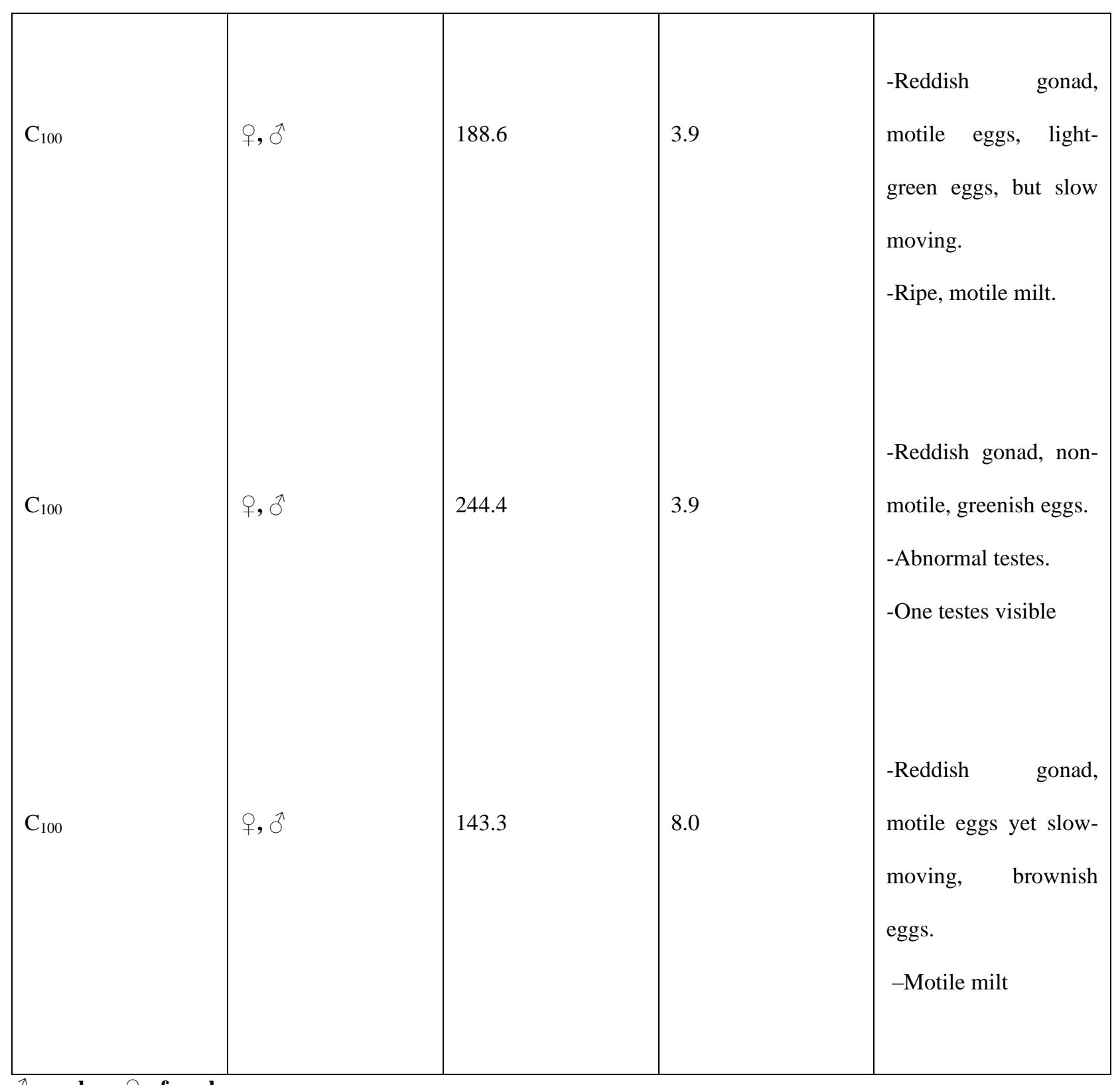




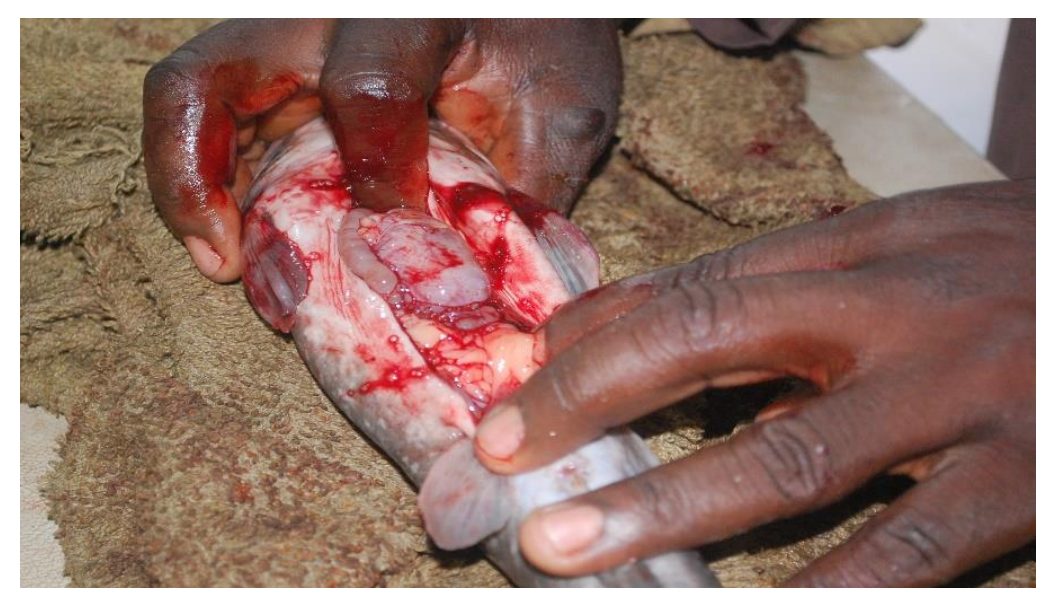

Plate 1 Dissecting a male Clarias gariepinus to remove the testes

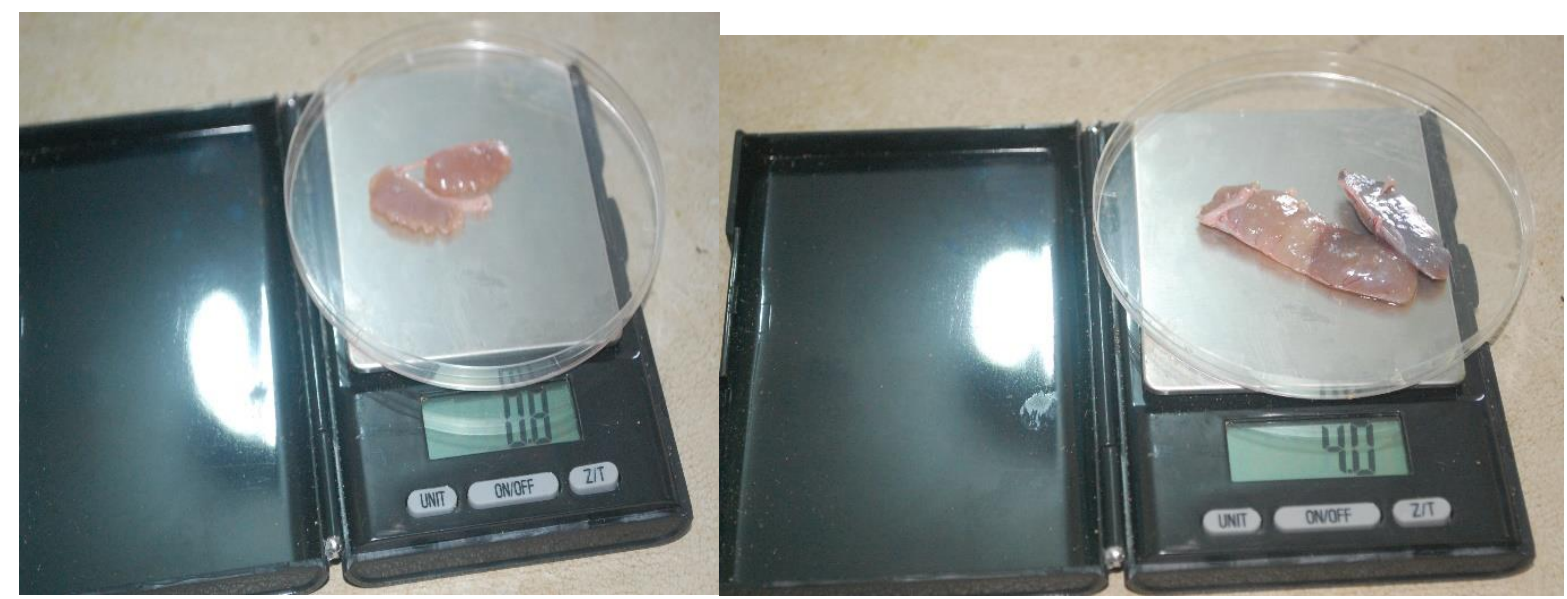

Plate 2 Pictures of some testes observed under the study

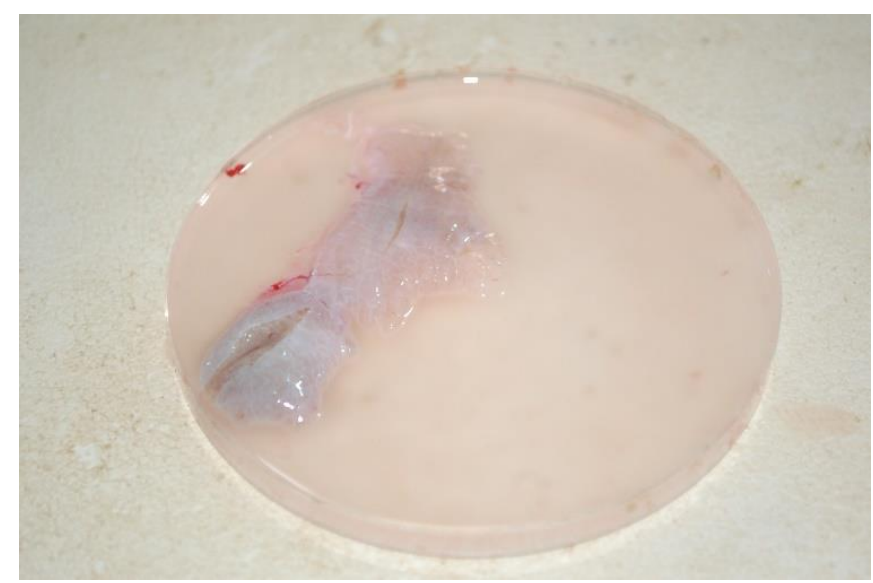

Plate 3 Picture of a watery milt observed under the study 


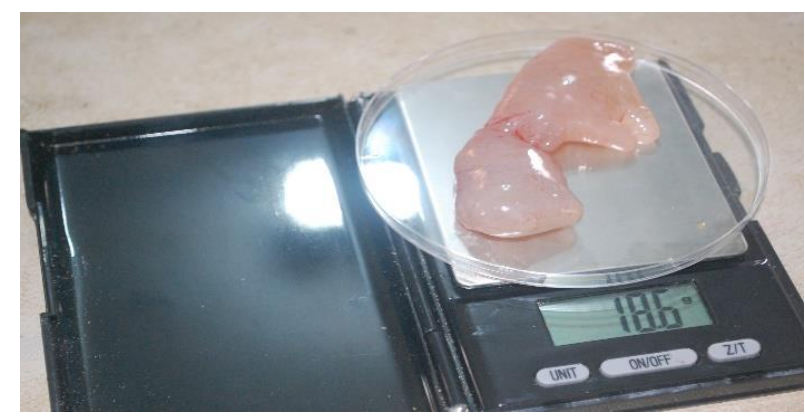

Plate 4 Picture of an abnormal looking testes

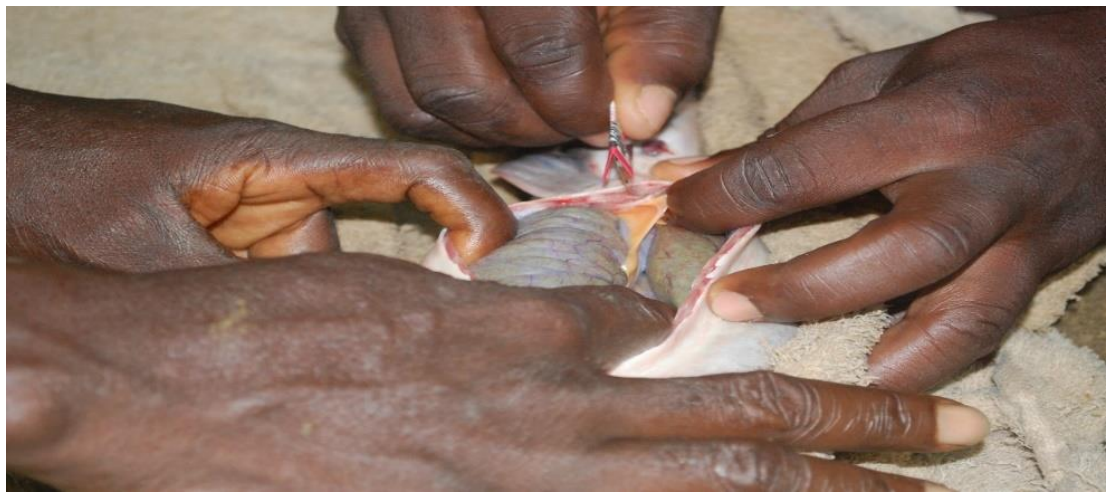

Plate 5 Dissecting a Clarias gariepinus female fish

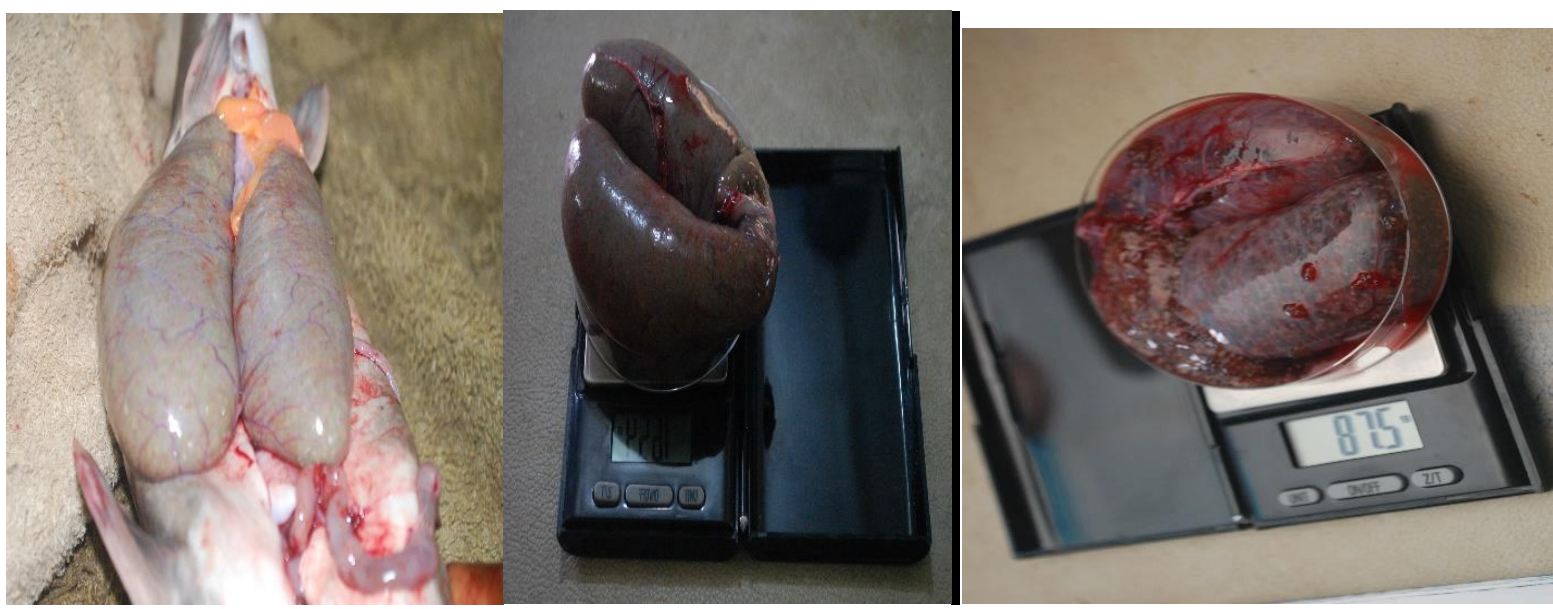

Plate 6 Abnormal looking gonads observed in the study 


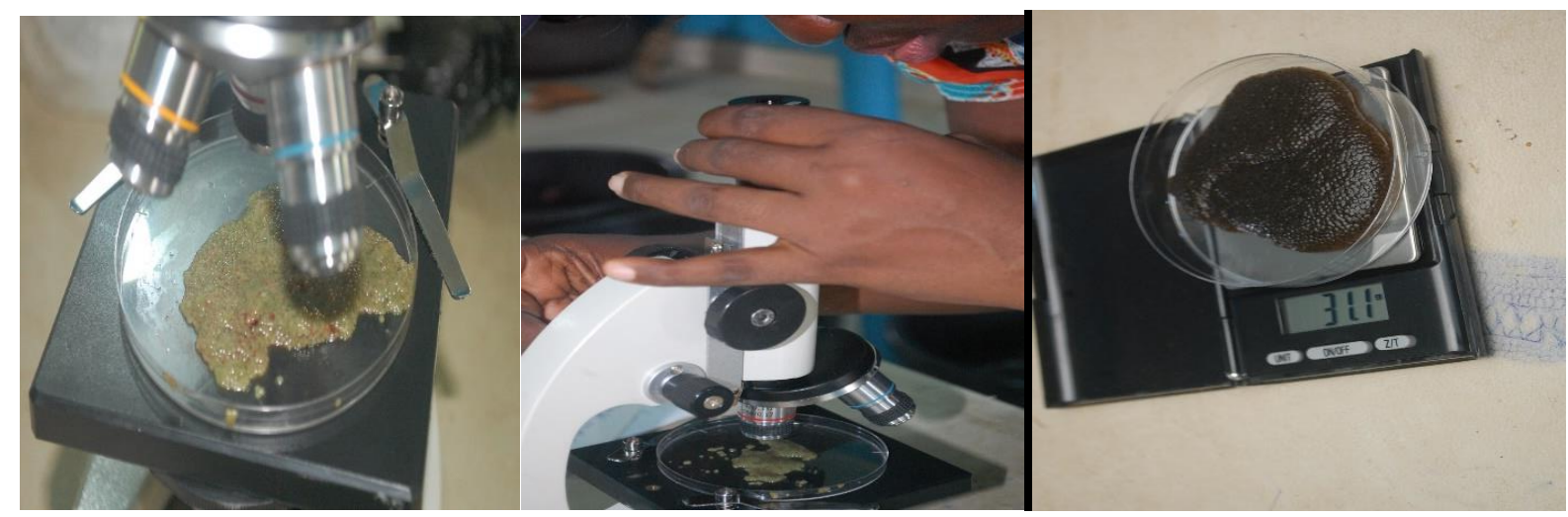

Plate 7 Pictures of some of the eggs released from the female Clarias gariepinus under study

\section{DISCUSSION}

Morphological study of the gonads revealed abnormal looking testes and gonads (one particular gonad had its eggs actively moving); an indication of a damaged organ structure due to the hormone, 17 $\alpha$-Methyltestosterone (MT) for which said fish was subjected to, during feeding. This does not agree with Turan and Cek (2007) in whose study, testes and gonads showed no damaged organ structure when Tribulus terrestris popularly called Gokshura was used on Clarias gariepinus. Tribulus terrestris is used in Europe, the Far East, China, India as a medicinal herb, helpful in treating sexual deficiencies, increasing testosterone and LH (Leutinizing hormone) levels in Clarias gariepinus. Tribulus terrestris is a steroidal sapronin responsible for sex-reversal in fishes. This study cannot conclude that the abnormalities were due to increased potency of the hormone in the treatments under study, as the abnormal gonads were seen in $\mathrm{C}_{50}$ treatment and the abnormal testes seen in $\mathrm{C}_{100}$ treatment. Previous reports have indicated higher levels of homones are responsible for abnormalities in fishes (Robert, 2021c). There were, reddish gonads seen in the study. Microscopic examination also revealed motile eggs and milt for most of the Clarias gariepinus fishes. This was indicative of the non-effectiveness of $17 \alpha$-Methyltestosterone (MT) in the gonads, testes of the fishes after feeding with the hormone ceased. This agrees with Guerrerro, (2008) who opined that hormone levels dropped in tilapia five days after hormone feeding stooped. Johnstone et al., (1983), Megbowon and Mojekwu, (2014) further revealed that 17 $\alpha$-Methyltestosterone (MT) was not detected in the whole body of a fish 100 hours after hormone treated diet. Amounts of $17 \alpha$-Methyltestosterone (MT) ingested by tilapia in a previous study was equal to $0.0-0.2 \mathrm{mg} / \mathrm{kg}$ MT/fish. This amount represents less than $0.01 \%$ of the normal daily dose of MT prescribed in human medicine which is $20-40 \mathrm{mg}$. This amount they suggested, reduces to less than $0.00001 \%$ of everyday human dosage a week after stopping hormone treatment. They, further reported that the testes of an adult human(man) gives out 15mg of endogenous testeosterone per day; yet only10mg of androgen is excreted daily. 


\section{CONCLUSION}

This report therefore recommends that, the fishes can be eaten or are safe for eating after hormone usage in their feed had stopped. This is because of the quick metabolism and subsequent excretion of hormones (especially $17 \alpha$-Methyltestosterone (MT) and 17- $\beta$ Estradiol $\left(\mathrm{E}_{2}\right)$, making it safe to consume hormone-treated product thereby facilitating the production of marketable sized fishes.

\section{REFERENCES}

Almeida, F.L. (2013). Applied endocrinology in fish reproduction technology. Brazillian College of Animal Reproduction, 37(2): 174180.

Ataguba, G.A., Annunne, P.A. and Ogbe, F.G. (2010). Growth performance of two African catfishes Clarias gariepinus and Heterobranchus longifilis and their hybrids in plastic aquaria. Livestock Research for Rural Development, 22(2): pp.6.

Guerrerro, R.D. (2008). Tilapia sex reversal. Retrieved from http://archive.today/OFxil

Hoga, C.A., Almeida, F.L. \& Reyes, G.R. (2018). A review on the use of hormones in fish farming: Analytical methods to determine their residues. Cyta-Journal of Food, 16: (1) 679-691.

Johnstone, R., Macintosh, D.J. \& Wright, R.S. (1983). Elimination of orally administered 17 $\alpha$-Methyltestosterone (MT) by Oreochromis mossambicus (tilapia) and Salmo gairdneri (rainbow trout) juveniles. Aquaculture, 35: 249-257.

Megbowon, I. \& Mojekwu, T.O. (2014). Tilapia Sex Reversal Using Methyl-Testosterone (MT) and its effect on Fish, Man and Environment. Biotechnology, 13: 213-216. doi: 10.3923/biotech.2014.213.216

Robert, E.A., Yisa, A.T. \& Tsadu, S.M. (2019a). Growth performance and survival of monosex cultured Heterobranchus longifilis juveniles in concrete flow-through and stagnant water systems. Scientific Research Journal (SCIRJ), 7(2): 43-65. doi: 10.31364/SCIRJ/v7.i2.2019.P0219615

Robert, E.A., Yisa, A.T. \& Tsadu, S.M. (2019a). Effects of 17 $\alpha$-Methyltestosterone (MT) on all-male sex reversal and determination, growth and survival of Clarias gariepinus juveniles in concrete stagnant water systems. Scientific Research Journal (SCIRJ), 7(2): 43-65. doi: 10.31364/SCIRJ/v7.i8.2019.P0819691

Robert, E.A. (2021c). Production of all-female Heterobranchus longifilis Juveniles reared in Recirculatory and Flow-through water tanks and fed feed mixed with 17- $\beta$ Estradiol $\left(\mathrm{E}_{2}\right)$. Book of Proceedings: The Freshwater Biological Association of Nigeria (FBAN), $3^{\text {rd }}$ Annual Conference, University of Uyo, Akwa Ibom State. 12 ${ }^{\text {th }}-16^{\text {th }}$ September,2021. pp: 73-76.

Turan, F. \& Cek, S. (2007). Masculinization of African Catfish (Clarias gariepinus) treated with Gokshura (Tribulus terrestris). The Israeli Journal of Aquaculture-Bamidgeh. 59(4):224-229.

www.sciri.org

(C) 2021, Scientific Research Journal

http://dx.doi.org/10.31364/SCIRJ/v9.i10.2021.P1021888

This publication is licensed under Creative Commons Attribution CC BY. 